\title{
"Countryside Cathedrals"? Communicating Meanings Through the Sacred Architecture of J.P. Dziekoński in the Diocese of Łomża within Its Current Borders. Part II
}

\author{
„Wiejskie katedry"? Komunikowanie znaczeń \\ w architekturze sakralnej J. P. Dziekońskiego na terenie \\ diecezji łomżyńskiej w obecnych jej granicach. Cz. II.
}

\begin{abstract}
:
This article revives the memory of a slightly forgotten architect Józef Pius Dziekoński and his work on the territory of today's Łomża diocese, putting it in the perspective of the communication theory. The popularity of Dziekoński's neo-Gothic structures, also known as "countryside cathedrals", is analyzed with the model of communicating symbolic messages (sender - architect; message - buildings; receivers - the faithful, onlookers). The decision on analyzing Dziekoński's works was influenced by two factors: 1) This architecture has not been sufficiently studied in respect of communicating meanings; 2) There has been no study to analyze only Dziekoński's churches built on today's territory of Łomża diocese. The aim of this paper is to present the historical and ideological context which determined the character of those sacred buildings and their communication role, especially as opposed to the ByzantineRussian architecture imposed at that time by the Tsarist administration.
\end{abstract}

KEYWORDS:

J.P. Dziekoński, communication, sacred architecture, Diocese of Łomża, neo-Gothic, Vistula-Baltic style

\section{STRESZCZENIE:}

W niniejszym artykule przypomina się sylwetkę i twórczość na obszarze obecnej diecezji łomżyńskiej nieco zapomnianego architekta warszawskiego, Józefa Piusa Dziekońskiego w perspektywie teorii komunikacji. Popularność neogotyckich budowli Dziekońskiego, nazywanych „wiejskimi katedrami”, zostaje zanalizowana przy pomocy modelu komunikacji treści symbolicznych (nadawca-architekt, komunikat-budowle, odbiorca-wierni, widzowie). Na podjęcie charakterystyki twórczości Dziekońskiego wpłynęły dwa zasadnicze czynniki: 1) architektura ta nie została wystarczająco dotąd zbadana pod kątem komunikowania znaczeń; 2) nie istnieje opracowanie analizujące wyłącznie kościoły Dziekońskiego na terenie obecnej diecezji łomżyńskiej. W prezentowanym tekście chodzi o przedstawienie kontekstu historycznego i programu ideowego, który determinował charakter omawianych budowli sakralnych i ich rolę komunikacyjną, zwłaszcza w opozycji do architektury bizantyńsko-rosyjskiej narzucanej w tym czasie przez władze carskie.

\section{SŁOWA KLUCZOWE:}

J.P. Dziekoński, komunikacja, architektura sakralna, diecezja łomżyńska, neogotyk 
Today's research is becoming increasingly interdisciplinary. The methods and methodologies are no longer property of particular disciplines; new types of observation and research are being developed, as well as new approaches to drawing logical conclusions, rules of analysis and ways of synthesizing. ${ }^{1}$ This also refers to the field where the social sciences and humanities overlap. In this area, the interactions between architecture and its users or onlookers, which can be referred to as communication, seem to be an interesting field of research. As over half a century ago Bernard Berelson noted: Communication is about communicating information, thoughts, emotions, impressions, etc., by means of symbols. ${ }^{2}$ Architecture is not mute, it speaks with symbols, semantics of their form and content. It speaks with its ideological program, role, aims for which it has been erected, shortly speaking: it communicates. Walery Pisarek writing about communication highlights the psychological (intellectual and emotional) facet of

\section{Architecture is not mute, it speaks with symbols, semantics of their form and content. It speaks with its ideological program, role, aims for which it has been erected, shortly speaking: it communicates.}

the message saying that: "Communicating psychological content - both intellectual and emotional - (...) by an individual (or individuals) A to an individual (or individuals) B is called communicating or informing." ${ }^{3}$ Undoubtedly, architecture includes a great deal of intellectual content with the potential of psychological influence.

Architects being senders of the "masonry" messages use various tools of artistic articulation drawing on symbolism, metaphor, tradition, cannon, style, or even a play, appearance or irony. ${ }^{4}$ Ever since the second half of the 19 th century

${ }^{1}$ C. Frankfort-Nachmias, D. Nachmias, Metody badawcze $w$ naukach społecznych, Poznań 2001, p. 28.

${ }^{2}$ B. Berelson, G.A. Steiner, Human Behavior, New York 1964, p. 254.

${ }^{3}$ W. Pisarek, Wstęp do nauki o komunikowaniu, Warszawa 2008, p. 17. 
when history of architecture crystalized as an independent area of study (then called "archeology of art") the researchers have been seeking for ways of reading, describing and defining the architectural messages communicated by means of signs. Phenomena perceived by our senses, signs are used in lieu of something else. ${ }^{5}$ In architecture, signs are communicated on three levels: 1) an idea expressed by the architect in his or her work, 2) the delivery of the idea (building); and finally 3 ) the way of reading the idea by the receiver, users or onlookers. ${ }^{6}$ This is a classical model of communication based on the trio made of the sender, the message and the receiver.

What was then meant to be communicated by the neo-Gothic churches by Józef Pius Dziekoński (1844-1927) erected in the late 1890s and early 1900s?

\section{THE ARCHITECT AS THE SENDER}

The first level of communication concerns the architect-sender's ideas. They constitute a preliminary stage, a creative inspiration. Thanks to their artistic imagination based on his or her professional experience, the architect-creator translates the ideas into designs and next - on the construction site - into actual buildings. The architect's ideas are not entirely autonomous because they are subject to constant updating and modification due to continuously changing social and cultural experience. The architectural message is based on the formal articulation of meanings, thoughts and images. As Jacek Krenz says: "The ideas and images included in this message make the bedrock of the final piece. Whereas the form is a kind of medium which communicates the message and, reaching the receiver, itself becomes the message."

Created based on the combination of those ideas, the building is a multi-layer message where information is communicated by signs of esthetic, intellectual or emotional character; all of them are present to different degree and extent. It is the architect who decides which one of them is to prevail; in other words, to what

${ }^{5}$ M. Lurker, Przesłanie symboli w mitach, kulturach i religiach, Kraków 1994, p. 24.

${ }^{6}$ J. Krenz, Idea ujęta $w$ kamień, http://www.pg.gda.pl/ jjkrenz/Az/Book3.html, access 23.07.2019.

${ }^{7}$ Ibidem. 
vision (function or idea) will the architect choose to subject the entirety of his or her creation (e.g. religious or political). ${ }^{8}$

Józef Pius Dziekoński was one of those architects of the turn of the century who lay foundations for the creative work infused with the "archeology of art" and "scholarly criticism", and which were connected with the naissance of the professional history of architecture on the Polish territory. ${ }^{9}$ An analytical look at the history of architecture established his reputation as one of the main figures of that time whose architecture harked back to history. ${ }^{10}$ Dziekoński's historicism

\section{Dziekoński's historicism was not a romantic longing for the mysterious atmosphere of the Middle Ages; He extensively used the achievements of the history of architecture which was being developed at that time.}

was not a romantic longing for the mysterious atmosphere of the Middle Ages; He extensively used the achievements of the history of architecture which was being developed at that time. In is work, Dziekoński drew on the leading designs of Austrian and German neo-Gothic (Votivkirche in Vienna ${ }^{11}$, façade along with a part of the main body of the cathedral in Cologne ${ }^{12}$ ), which he creatively trans-

${ }^{9}$ A. Majdowski, $O$ „archeologii sztuki i krytycyzmie naukowym” w polskiej architekturze sakralnej drugiej połowy XIX wieku, Nasza Przeszłość: Studia z dziejów Kościoła i kultury katolickiej w Polsce, Kraków 1991, Vol. 76, pp. 295-313.

${ }^{10}$ K. Stefański, Nowa forma $w$ polskiej architekturze sakralnej poczq̨tku XX wieku: Wojciechowski-Sosnowski-Wiwulski, „Saeculum Christianum: pismo historyczno-społeczne” 2003, No. $10 / 2$, p. 310.

${ }^{11}$ The building underscoring the greatness of the Habsburgs, founded in Vienna as a gratitude for saving the life of the royal successor, the young Franz Josef I, who was targeted in an assassination attack in 1853; The church was built in 1855-79 and was designed by Heinrich von Ferstel.

${ }^{12}$ The construction works of the Cologne cathedral started in 1248 . The works were stopped by the Reformation; the construction was accomplished in 1842-1880. 
formed based on the Polish Gothic heritage. ${ }^{13}$ In his works of architecture, he was aiming to encapsulate a creative synthesis of the Polish and European Gothic architecture, not by copying but by using the existing buildings as an inspiration. As he wrote: "I do not study history of the pieces of architectural heritage; when building them, I take the position of pure art."14

Dziekoński's sacred architecture of the turn of the century delivers on the postulates appearing among the public, in the press and archive sources, calling for initiatives to erect buildings which would hark back to historical heritage and

\section{Dziekoński's sacred architecture of the turn of the century delivers on the postulates appearing among the public, in the press and archive sources, calling for initiatives to erect buildings which would hark back to historical heritage and be as beautiful, great and magnificent as the medieval Gothic cathedrals. Those proposed projects were supposed to echo the grandness of the ancient Polish architecture.}

be as beautiful, great and magnificent as the medieval Gothic cathedrals. ${ }^{15}$ Those proposed projects were supposed to echo the grandness of the ancient Polish architecture. Following the historicist approach in his work to such a wide extent,

${ }^{13}$ J. Dziekoński, Kościół parafialny ś-go Floryana na Pradze, „Architekt”, No. 1 (1900), p. 6. See A. Majdowski, O poglądach na styl wiślano-bałtycki w polskiej architekturze sakralnej XIX wieku, in: Nasza Przeszłość: Studia z dziejów Kościoła i kultury katolickiej w Polsce, Kraków 1992, Vol. 78, p. 324, footnote 69.

${ }^{14}$ J. Dziekoński, Kościół NP. Maryi w Krakowie, „Przegląd Techniczny” 15 (1889), p. 92. See A. Majdowski, O poglądach..., op. cit., p. 323, footnote 65.

${ }^{15}$ Cf. W.F. Wilczewski, Zwiastun powszechnej radości. Ruch budowy kościołów $w$ diecezji wileńskiej w latach 1890-1914, Białystok 1995, p. 33. 
Dziekoński shared the postulates made by some journalists ${ }^{16}$ and part of technically-minded intelligentsia ${ }^{17}$ on the need of seeking the national style, which he balanced with his extensive historical and architectural knowledge. However, he did not share the ideas of some architects and theorists like Jan Sas-Zubrzycki ${ }^{18}$, whose suggestions Dziekoński assessed as extreme if not chauvinistic. Dziekoński was convinced of the value of maintaining the historical truth. He was extremely meticulous about the authenticity of the building structure and its particular elements, especially details, calling it: "the craft perfection of a given time". ${ }^{19}$ This Warsaw architect was critical of the common practice of making ribs of plaster; In his opinion, using ribs as an inherent part of the structure and withstanding the lure of adding artificial rib vaults was evidence of "architect's sagacity". ${ }^{20} \mathrm{On}$ the other hand, he felt the pressure from the younger generation of architects who were looking for new inspirations and solutions in modernism (among others they included Adolf Szyszko Bohusz, Czesław Przybylski, Oskar Sosnowski, Jarosław Wojciechowski, Zdzisław Mączeński). ${ }^{21}$ The modernist architects did

${ }^{16}$ Cf. F.K. Martynowski, Zapoznane drogi w sztuce polskiej, „Przegląd Bibliograficzno-Archeologiczny" 1881; K. Matuszewski, O architekturze u obcych i u nas. Uwagi ze stanowiska estetycznego, „Biblioteka Warszawska”, Vol. 3, 1881.

${ }^{17}$ This approach was especially vigorously (sometimes even chauvinistically) criticized by Jan Sas-Zubrzycki who wrote: "Now, you treat Matejko painting as degenerate historicism, a mistake and perversion. (...) Whereas in architecture, quite on the contrary, you strive to seek for ancient home references (...)". See J. Sas Zubrzycki, Styl polski styl narodowy, Lwów 1922, p. 59.

${ }^{18} \mathrm{~J}$. Dziekoński, Księgi o architekturze d-ra Zubrzyckiego, „Przegląd Techniczny” 41 (1915), p. 321. See A. Majdowski, 0 poglądach..., op. cit., p. 325, footnote 79.

${ }^{19}$ In the 19th century, it was common practice to add artificial ribs made of plaster along the lines of the intersection in groin vaults to create an illusion of features characteristic of the Gothic rib vaults. See J. Dziekoński, Budowanie kościołów z cegły palonej, „Przegląd Katolicki” 1894, p. 615. See J. Żywicki, Nurt neogotycki w architekturze sakralnej międzyrzecza Wisły i Bugu, in: Nasza Przeszłość: Studia z dziejów Kościoła i kultury katolickiej w Polsce, Kraków 1996, Vol. 85, p. 301, footnote 86.

${ }^{20}$ Ibidem.

${ }^{21}$ Incidentally, it seems worth noting that in 1901 -1913 the above mentioned Zdzisław Mączeński, before he developed his own individual style, was Dziekoński's student and was involved in delivering some of his neo-Gothic projects in Łomża diocese. He greatly contributed to the design and construction oversight of the churches in Rzekun (1902-1905), Poświętne (1906), Zuzela (1906), Puchały (1906), Długosiodło (1906) and he was involved in designing the churches in Kulesze (1909), and Wąsewo (1911). Mączeński was the author of charts and measurements for Dziekoński's designs, as well as the correspondence 
not compromise the postulate of adding national features to architecture. On the contrary, they were quite creative in that though remaining in opposition to historicism: they were successful in showing the elements of Polishness arranged in the modernist style. ${ }^{22}$ Functional focus as the leading principle of modernist architecture was then the most modern approach and a new paradigm of architecture. ${ }^{23}$ Paradoxically, also Dziekoński's neo-Gothic designs included some elements of the functional approach. In his structures, one could discern construction elements which were only as massive as it was absolutely necessary, freeing the walls from their load-bearing function. In the modernist style, the same was delivered by means of entirely new technologies and material, mainly with reinforced concrete and steel. ${ }^{24}$

In his historicism-infused approach Dziekoński did not restrict himself only to the neo-Gothic styled buildings. Apart from his fascination with the neo-Gothic, he was also interested in the so-called "transitory style" and eclectism (e.g. the Warsaw Church of the Holiest Savior). Perhaps this way he wanted to avoid the cliché of the so-called Vistula-Baltic style ${ }^{25}$ and assert his belief that nation-

and documentation of the conservation works. From his diaries you can also learn that apart from the above mentioned churches, in 1908, a church for the Białoszewo parish (the Łomża diocese) was designed; however, this project was never delivered. W. Jemielity, Schematyzm diecezji łomżyńskiej, Łomża 1975, p. 101. Pamiętniki architekta Zdzisława Mączeńskiego. See A. Majdowski, Stan badań..., op. cit., p. 251, footnote 10; p. 251, footnote 11.

${ }^{22}$ Their voices converged with the ideas championed by architects and conservation professionals of the turn of the century for whom overusing the historical styles (especially the so called Vistula-Baltic one) was treated as forgery. The feeling of being tired of historicism echoed, among other things, in the speech given by Fr. Gerard Kowalski, during the First Rally of the National Heritage Aficionados in Cracow in 1911, where he asserted that the VistulaBaltic style was a mistake and anachronism; he accused the investors to be keen on delivering another "pseudo-Gothic cathedral", and not a piece of genuine architecture. See G. Kowalski, Wiejskie kościoły i ich konserwacja, in: Pamiętnik Pierwszego Zjazdu Miłośników Ojczystych Zabytków w Krakowie w dniach 3 i 4 lipca 1911 roku, Kraków 1912, p. 65.

${ }^{23}$ Antonio Sant'Elia, an Italian futurist, in his manifesto, criticized architects that for over a century they had failed to move on: "Since the 18th century, there has not been any architecture." See A. Sant'Elia, Manifest futurystyczny; Source: B. Świt-Jankowska, Znaczenie w architekturze detalu, „Czasopismo Techniczne. Architektura” 109 (2012), z. 5-A/2, p. 593; Available online: https://suw.biblos.pk.edu.pl/downloadResource\&mId=1088182, access: 23.07.2019.

${ }^{24}$ Medievalman0, Architektura gotycka a scholastyka, https://medievalman0.wordpress. com/2009/10/16/architektura-gotycka-a-scholastyka/, access: 5.07.2019.

${ }^{25}$ The synthesis of the history of the so called Vistula-Baltic style is given by Andziej Majdowski in his article: O poglądach na styl wiślano-bałtycki w polskiej architekturze sakralnej 
al elements in architecture go beyond the boundaries of individual styles. ${ }^{26}$ The transitory style was a mixture of the Romanesque and Gothic features (aka "Piast architecture"). While in the Gothic architecture, Dziekoński mainly found the symbolic yearning of the soul to heaven, in the Romanesque style it was misterium tremendum, the fear of sin and God..$^{27}$ The elements of the transitory style are to be found in Dąbrowa Wielka and Wąsewo.

\section{ARCHITECTURE AS A MESSAGE}

The second element of the communication model is the message itself - in this case it is Dziekoński's churches on the territory of Łomża diocese. As Jacek Krenz writes: "The delivery of the intention articulated in the architectural form is performed by the use of design experience, and the principles of creating a given form like: symmetry, rhythm, climax, concentration, continuity, contrast, etc. In this workshop phase of the creative process, there comes to the material realization of the idea based on the building craft, making informed choices about the right building materials, being aware of their texture, color and construction properties. It is the architect's awareness and skills that determines if the translation of ideas into a spatial form will make the form a medium of communicating intentional messages." 28

Monumentality and historicism, characteristic of Dziekoński's churches, were achieved thanks to drawing on specific architectural forms: wide and slender tower façades inspired by Gothic, the division and verticalism of naves and aisles. Dziekoński consistently used tower façades (usually twin/two towers,

XIX wieku, in: Nasza Przeszłość: Studia z dziejów Kościoła i kultury katolickiej w Polsce, Kraków 1992, Vol. 78 (accessible on: kpbc.umk.pl - access: 23.07.2019)

${ }^{26}$ As Andrzej Majdowski writes: „It seems to be admissible to assert that in the sacred architecture those changes find their origins in the Warsaw Savior church which set up one of the directions to be followed in ambitious and creative endeavors to define the national architecture to be, shortly thereafter, referred to as the Polish style". See A. Majdowski, Stan badań nad twórczościq Józefa Dziekońskiego w zakresie architektury sakralnej: $w 150$ lecie urodzin architekta, „Ochrona Zabytków” 47/3-4 (1994), p. 266.

${ }^{27}$ Cf. W. Bałus, Gotyk bez Boga? W kręgu znaczeń symbolicznych architektury sakralnej XIX wieku, Toruń 2011, p. 121.

${ }^{28}$ J. Krenz, Idea ujęta w kamień, http://www.pg.gda.pl/ jkrenz/Az/Book3.html, access: 23.07.2019. 
rarely a single one) to flank the western front of the building..$^{29}$ It was only in $\mathrm{Zu}$ zela that he chose not to design a tower for the front façade. ${ }^{30}$ The character of the towers was historically conditioned: the lofty towers flanking western fronts were commonly associated with the Western Christianity in contrast to the condensed, domed designs typical of the Orthodox churches (since the 6th century they have been a place to hang church bells). ${ }^{31}$ The twin-tower façades were notable for majestic grandiosity, being an optical framework for the entire structure, and moreover, they highlighted the axiality and verticalism of the design. ${ }^{32}$ In the single-tower buildings the tower was pushed into the façade centrally following the main axis of the church.

In the late 1890s, in the Mazovian province, the aesthetic attractiveness of the twin-tower façades undoubtedly arose from the strength of the monumental design of the St. Florian church in Praga, Warsaw, which made a signature piece of the architect's style. ${ }^{33}$ The elegance of the church's towers was based not only on the ornaments but also appropriate proportions: the towers are twice as tall as the main body (although nowadays on the territory of the Łomża diocese they often are lower than originally due to the destruction suffered during the

${ }^{29}$ Historically, the twin-tower façades were usually reserved for buildings of greater importance, mainly cathedrals or municipal churches; In the country, smaller, usually singletower churches were built. One should point out here the role of the great French late Gothic cathedrals: "Since regularity and symmetry were the essence of the neo-Gothic style, architects strove to create "archeologically ideal" picture of the Gothic architecture drawing on its best stage of development." Source: J. Żywicki, Architektura neogotycka..., op. cit., p. 79.

${ }^{30}$ This decision could have been well thought-out because it allowed for a greater design capabilities of the façade thanks to using decorative ogive blind windows and openings in walls.

${ }^{31}$ Jan Sas Zubrzycki ascribed virtually mystical meaning to the slender towers topped with crosses: „the cross towering over anything: this is the Gothic slogan”; There he poetically added, not without a hint of patriotism: "The style of medieval Polish chroniclers makes an example to be followed for the style of our Gothic towers: proud, grand - lofty, poetic, dreaming, and still confident and bold." See J. Sas Zubrzycki, Styl nadwiślański, Kraków 1910, p. 51-52.

${ }^{32} \mathrm{~K}$. Kleczkowski wrote that the church tower made "an impression of a spiritual dominance over anything material in its vicinity below." See K. Kleczkowski, Analiza kształtów architektury, Warszawa 1885, p. 50.

${ }^{33}$ As Jerzy Żywicki writes: "The fact that in the 1890s there started appearing twintower neo-Gothic churches must have been the consequence of a common influence of some model pieces of architecture like Votivkirche in Vienna, the cathedral in Cologne, and, in the first place, the St. Florian church in Warsaw." See J. Żywicki, Architektura neogotycka na Lubelszczyźnie, Lublin 1998, p. 79. 
Second World War and later inaccurate reconstructions). ${ }^{34}$ In the most grandiose designs, the towers in their upper sections could turn from quadrangle into octangle (like in the St. Mary's Basilica in Cracow). One can find this solution in Poświętne and Wąsewo where quadrangular towers make the basis for octangular belfries topped with slender spires. As a rule, the towers had three sections corresponding with their three functions: at the ground level was the narthex, one level above was the choir or its back room and in the uppermost section was the belfry topped with the helm and spire. Some towers had more stories (e.g. the one in Dąbrowa Wielka has five). The towers were topped with helms with slender spires, sometimes, like in Poświętne, they drew on well-known solutions: the helm of the higher tower of the St. Mary's Basilica in Cracow. ${ }^{35}$

In the majority of cases, in his designs, Dziekoński designed three-nave hall churches or - more rarely - three-nave basilicas; only occasionally were they single nave structures. The three-nave halls were prevalent for historical and technical reasons. ${ }^{36}$ The hall structure is to be found in the churches erected in Długosiodło, Kulesze Kościelne, Poświętne, Rzekuń, Wąsewo and Zuzela. The basilica structure was used only in Dąbrowa Wielka. With a conscious choice of symbols as well as the Gothic reference, the churches were built with transept or pseudotransept. Thanks to this the buildings gained a distinct outline of the Latin cross in their floor plan (in contrast to the Orthodox churches built on the plan of the Greek cross). ${ }^{37}$ Additionally, Dziekoński might have taken into account the

${ }^{34}$ High towers were also of the ideological and military importance. As Jerzy Żywicki noted: "During the First World War the 'military' function was actually used again them. The retreating Russian troops blew them up. Although it served only as an excuse, they were deemed to be comfortable observation posts and thus fell prey to the desire of destroying them." See J. Żywicki, Architektura neogotycka..., op. cit., p. 78

${ }^{35}$ The tower façade in Poświętne can make a good case in point here: "In line with the main axis of the façade, there is a grand tower, pushed into the main body in its lower part. This is a quadrangular, four-tier tower, with the octangular top tier roofed with an octangular helm and a half-tier in its lower part made of eight bay windows, with arched window-like openings, roofed with gable helms, surrounding the spire with a crown placed in the middle of its height. The spire is topped with a pinnacle with the cross and a weather vane". See Katalog Zabytków Sztuki w Polsce. Województwo podlaskie (białostockie). Powiat białostocki, ed. M. Zglińskiego, K. Kolendo-Korczak, Warszawa 2016, p. 179.

${ }^{36}$ Cf. J. Żywicki, Architektura neogotycka..., op. cit., p. 77.

${ }^{37}$ A. Nowowieyski, Wykład Liturgii Kościoła Katolickiego, Vol. 1, Wiadomości wstępne, part I, O środkach rozwinięcia kultu, Warszawa 1893, p. 140. 
practical considerations: in the arms of the transept one could place occasional liturgy-related decorations (e.g. Tomb of Jesus, Altar of Repose with the vailed ciborium, etc.). ${ }^{38}$ At the crossing of the transept with the nave or on the eastern top, he usually placed ridge turrets (e.g. which have been either preserved or rebuilt in Dąbrowa Wielka, Długosiodło, Kulesze, Rzeuń or Wąsewo).

For Dziekoński it was the brick that was predominantly his first choice as both the basic building material as well as decorative one, although in his designs he used architectural ornaments carefully. Dziekoński put the greatest decorative focus on the front walls, especially their upper parts: he decorated them with blind windows, lisenes, mullions, blind niches, spires and pinnacles. ${ }^{39}$ The walls were fashioned with friezes, mouldings, blind niches, ogive-shaped surfaces and plastered blind windows which were used to contrast the surfaces (e.g. a thin colored frieze under the overhang in Rzekun or color-contrasted front façade in Długosiodło and Wąsewo, crow-step tops (closing the aisles in Zezula). ${ }^{40} \mathrm{He}$ obtained the rhythm of the vertical structure of walls by combining them with slanting buttresses reinforcing the walls. ${ }^{41}$ In the classical design of the Gothic basilicas the buttresses came along with flying buttresses; on the territory of the Łomża diocese, the best examples thereof are to be found in Dąbrowa Wielka, where they tower above the roofs of aisles (however, they are not so sophisticated as the ones in the St. Florian church in Praga, Warsaw).

\section{THE RECEIVER}

The third component of the communication of architecture are the receivers, i.e. the faithful and onlookers. As Jacek Krentz writes: "The ability to read those meanings depends on the perception capacity of the receiver, their emotional and

${ }^{38}$ J. Żywicki, Architektura neogotycka..., op. cit., p. 78.

${ }^{39}$ As Piotr Krakowski writes: „The popularity of the brick architecture predominantly hinged on its actual strengths: color effect giving a real opportunity to monumentalize color in architecture; next, the simplicity and easy and solid structure, possibility of effective combination with other materials, both for design and esthetic reasons; or, finally, actual large scale supply of brick." See P. Krakowski, Fasada dziewiętnastowieczna. Ze studiów nad architektura XIX wieku, „Zeszyty Naukowe Uniwersytetu Jagiellońskiego. Prace z Historii Sztuki”, issue 16, 1981, p. 61. 
rational awareness, as well as social and intellectual circumstances." ${ }^{\prime 2}$ The perception of the faithful (onlookers, receivers) is the indicator of the meaning and communicative activity. What becomes interesting then for a researcher studying this topic is to answer the question of how Dziekoński's churches were perceived at the turn of the century. Why were they so desired and popular? How did the social and political situation affect the perception and judgements that the Teutonic links and provenience were ignored? How were the signs and symbols included in specific architectural forms read in the historical and cultural situation of that time?

In many cases, in the parishes of the Łomża diocese, the investments and other sacred undertakings at the turn of the century were conducted with enthusiasm and generosity of the people. ${ }^{43}$ This enthusiasm was a product of the social and historical situation. The oppressive attitude of the Tsarist authorities and common problems to obtain a permission to build churches made people inclined to build grand buildings whose dimensions exceeded the needs of the local communities. ${ }^{44}$ And because to finance those projects one could not - as it was the case before - count on great donations from aristocratic families, the churches were predominantly built from the means of the local communities (e.g. the church in Dąbrowa Wielka was built solely from the funds raised among the local lesser nobility).

Dziekoński's professional activity concurred the time of reawakening of the national identity, defining the historical, cultural and religious identity. ${ }^{45}$ Drawing

${ }^{42}$ J. Krenz, Idea ujęta $w$ kamień, http://www.pg.gda.pl/ jkrenz/Az/Book3.html, access: 23.07.2019

${ }^{43}$ A. Nowowieyski, Wykład Liturgii..., op. cit., p. 187.

44 "It's better to make it too big than to make the future generations extend it." See A. Brykczyński, Dom Boży to jest praktyczne wskazówki budowania, naprawiania i utrzymywania kościołów na wzór dzieła X. Montault, Warszawa 1988, p. 10.

${ }^{45}$ Attempts to create a national style in architecture in countries like Hungary, Norway, Finland, Romania, Poland appeared part of a wave of so called "national romanticism" in the 1880s. At the beginning they drew on the high art. In Czechia, Antonin Wiehl referred to renaissance. In Romania, the so-called neo-Romanian style was created, based on the Romanian architecture of 17th and 18th centuries when it was in its heyday. In Hungary, Ödön Lechner contributed to the creation of so-called Hungarian style: he designed buildings combining baroque and oriental motifs (the latter ones were to refer to the eastern origins of Hungarians). In Scandinavia, architects used the Nordic traditions, especially the ones originating from the Norman times. In Norway the Dragestil architecture drew on the tradition of the Romanesque 
on the known styles of architecture people tried to define the style which would best fit the character of national architecture. It was about indicating specific forms for a given country or community and they were to be a carrier of meanings - of national, patriotic, or religious character - for the creator of a piece and for the receiver, of which they were to be aware. ${ }^{46}$ In some countries, the national style construed that way was a tool of national and religious domination (e.g. the transformed Byzantine architecture in the Russian empire ${ }^{47}$, whereas in others it was a way of defying foreign dominance and marking their own individuality (e.g. Dziekoński's neo-Gothic in Poland). ${ }^{48}$ On the Polish territories ruled by Tsarist Russia it was about looking for separateness in the field of culture, defying the imposed Byzantine-Russian style. Following the fall of the January Uprising there came a wave of the most ruthless persecution in response to any signs of Polishness or Catholicness. Any signs of autonomy were abolished in order to conduct not only unification with the Russian empire but a large-scale Russification and nationality-related brain-wash. The Polonized people of Podlasie were forcedly included into the Orthodox Church (the martyrdom of the Uniates of Podlasie). ${ }^{49}$ Part of the persecution aimed at the Catholic Church was effective intimidation

stave churches (stavkirke); similar projects are to be found in Finland and Sweden. In Scandinavia, it was, among others, Martin Nyrop who designed buildings based on the national style of wooden and masonry architecture.

${ }^{46}$ The plan to create the national style was pursued in almost entire Europe (especially in Germany, Central and Eastern Europe: Czechia, Hungary, Romania, Scandinavia, Russia, Poland) and beyond (e.g. in the USA, Japan or Turkey).

${ }^{47}$ In Russia, the pursuit of the national style marked in the first half of the 19th century. The style drew on the traditional forms of the Orthodox-Byzantine and local architecture. In the 1820s, Wasiliy Stasov designed two Orthodox churches (in Kiev,1826-1830 and Potsdam, 1827-1832). The style was chiefly popularized by Konstantin Thon who designed the Spasky Sobor (1839-1843) and the Kremlin palace in Moscow (1839-49). From the 1850s on, the Byzantine style was considered the Russian national style. On the territories of conquered countries, it came to be a symbol of Tsar's absolute rule, Russification and the domination of the Eastern Orthodox Church. That style was especially badly received on the Polish territories: it became par excellence a symbol of occupation and Russification.

${ }^{48}$ The need to pursue the national style appeared in Europe or in small countries at the time of changes that were pivotal to their independence (e.g. Catalonia, Ireland) or in the countries which aspired to play a greater role than they actually did (e.g. Germany, Russia).

${ }^{49}$ J. Pruszkowski, Martyrologium, czyli męczeństwo unii na Podlasiu, part 1-2, Lublin 1905-1917; Zanim wróciła Polska. Martyrologium ludności unickiej na Podlasiu w latach 18661905 w świetle wspomnień, Vol. 5, prepared by T. Krawczak, Warszawa 1994, pp. 21-160. 
activities against the clergy (among other things six out of seven diocese bishops were ousted from their offices). Defiant bishops and priests were deported to the remote territories of Russia; this was the lot of, among others, Konstanty Ireneusz Łubieński, the bishop of Sejny. ${ }^{50}$ Although he supported a conciliatory approach to the relationship with Russia (among other things, he condemned the January Uprising). ${ }^{51}$ There was hope only for those priests who were totally submissive to the Russian authorities. With the Catholic hierarchy brutally muted, it was designing and delivering the sacred architecture that took over the role of the "advocate" of the Church and the People. Neo-Gothic churches represented sharp
With the Catholic hierarchy brutally muted, it was designing and delivering the sacred architecture that took over the role of the "advocate" of the Church and the People. Neo- Gothic churches represented sharp contrast to the Byzantine-Russian style imposed by the Tsarist authorities, and became a tool to shape the religious and national identity based on its affiliation to Western Latin civilization.

contrast to the Byzantine-Russian style imposed by the Tsarist authorities, and became a tool to shape the religious and national identity based on its affiliation to Western Latin civilization.

${ }^{50}$ Bp Konstanty Łubieński, in: Słownik biograficzny, Warszawa 2000, kol. 266-267.

${ }^{51}$ M. Banaszak, Historia Kościoła katolickiego, Vol. III, part II Czasy nowożytne 1758-1914, Warszawa 1991, p. 306. The competences of this college to some extent overlapped with the Eastern Orthodox Holy Managing Synod (Świqtobliwy Synod Rządzący) chaired by oberprokurator, who was a layman. 


\section{CONCLUSION}

The course of history, although relentlessly pressing ahead, surprisingly keeps repeating itself in various cultural phenomena. On the Polish territory, there ran a division line (which at the same time was a bridge) between the culture of the West (Latin, European) and East (Byzantine-Russian, Russian, Asian). Those division lines affected the national and religious identities. It resulted in a system of symbols relevant for the cultural identity and sense of belonging, and one of its manifestations - the topos of the Gothic cathedral as a distinctive feature of being part of the Latin, West-European civilization. How persistent this topos has been is to be seen in the words of Fr. Janusz St. Pasierb, a distinguished art historian and a poet. What Józef Pius Dziekoński experienced and communicated through the neo-Gothic architecture at the time of the partition of Poland, at the time of the Communist Poland was felt by Fr. Pasierb: How to explain the fact that following the hardship of the Second World War, we wanted to create our new past, reconstructing the cathedrals in Warsaw, Gniezno or Poznan in the Gothic style, if not by the desire to highlight our own European identity? (...) Europe has always been a construct, a work of culture. Looking at the map, you can see only Eurasia. Europe is not distinctly separated from Asia. To the East, its borders are drawn by culture. ${ }^{52}$

As a result of the described circumstances of political and historical nature, at the turn of the century the landscape of the Łomża diocese in Mazovia and Podlasie started to fill up with churches being a kind of Gothic "countryside cathedrals", as they were referred to by Andrzej Majdanowski, Dziekoński's monographer. ${ }^{53}$ On the territory of the Łomża diocese (within its today's borders) as many as eight Dziekoński's churches were built in the brick Gothic style, common in the medieval Poland. ${ }^{54}$ One could assert then that the popularity of the neo-Gothic architecture in the Łomża region at the turn of the century was not accidental,

${ }^{52}$ J. St. Pasierb, Katedra symbol Europy, Pelplin 2004, pp. 28-31.

${ }^{53}$ A. Majdowski, Nurt narodowy w architekturze sakralnej Królestwa Polskiego od drugiej połowy XIX wieku, in: Studia z historii architektury sakralnej w Królestwie Polskim, Warszawa 1993, p. 127.

${ }^{54}$ The first fully brick buildings were built in Silesia (Wrocław castle and Cistercian monastery in Lubiąż) and in Pomerania (the Cistercian abbey in Oliwa) built in late 12th century. In Mazovia, Gothic appeared with the growing influence of commercial and cultural relationships with the State of the Teutonic Order. See E. Małachowicz, Wrocławski zamek ksiazzęcy i kolegiata św. Krzyża na Ostrowie, Wrocław 1993, pp. 31-36; L. Wetesko, Romańska i wczesnogotycka 
but it was a product of the historical circumstances and the social and religious situation. To analyze that situation, it seems useful to use the communication perspective. Dziekoński's extensive references to the ancient Gothic architecture had some communicative motivations - there were religious and patriotic ideas which were a symbol of the defiant attitude of the Polish public towards the religious and political discrimination and persecution and mass Russification campaign that came in the wake of the January Uprising. ${ }^{55}$ Dziekoński believed that in then contemporary historical circumstances the medieval Gothic style was the most appropriate and the most logical choice." ${ }^{16}$ His architecture was a form of communication: it became one of few "books", which remained outside the reach of the Russian censure apparatus. ${ }^{57}$ Thus, Dziekoński's architecture expressed that it belonged to the Polish culture in the Latin civilization, and as such it was a manifest of resistance towards the foreign culture forcibly imposed by the foreign power. ${ }^{58}$

\section{BIBLIOGRAPHY}

Bałus W., Gotyk bez Boga? W kręgu znaczeń symbolicznych architektury sakralnej XIX wie$k u$, Toruń 2011.

Banaszak M., Historia Kościoła katolickiego, Vol. III, part II Czasy nowożytne 1758-1914, Warszawa 1991.

Bania Z., at al., Zabytki architektury w Polsce, in: Zarys problematyki ochrony zabytków, Warszawa 1996.

Berelson B., Steiner G.A., Human Behavior, New York 1964.

architektura kościoła pocysterskiego w Oliwie (XII- XIII w.), in: Nasza Przeszłość: Studia z dziejów Kościoła i kultury katolickiej w Polsce, Kraków 1994, Issue 83, pp. 438-439.

${ }^{55}$ For example, the neo-Gothic parish church in Białystok (nowadays archcathedral) was considered a "masonry commentary" to the history of persecuting Polishness and Catholicism by the Russian authorities. Similarly, in the lands annexed by Prussia, neo-Baroque was a response to the spread of the neo-Gothic style. Cf. Z. Bania, Zabytki architektury $w$ Polsce, in: Zarys problematyki ochrony zabytków, Warszawa 1996, p. 81.

${ }^{56}$ J. Dziekoński, Budowanie kościołów z cegły palonej, „Przegląd Katolicki” 1894, p. 615. See J. Żywicki, Nurt neogotycki w architekturze sakralnej międzyrzecza Wisły i Bugu, in: Nasza Przeszłość: Studia z dziejów Kościoła i kultury katolickiej w Polsce, Kraków 1996, Vol. 85, p. 301, footnote 86.

${ }^{57}$ Cf. A. Nieniewski, Architekt Józef Dziekoński, „Przegląd Techniczny” R. 1908, No. 1, p. 13. See A. Majdowski, Nurt narodowy..., op. cit., p. 37.

${ }^{58}$ See A. Majdowski, Nurt narodowy...., op. cit., p. 134, footnote 115, p. 136. 
Brykczyński A., Dom Boży to jest praktyczne wskazówki budowania, naprawiania i utrzymywania kościołów na wzór dzieła X. Montault, Warszawa 1988.

Dziekoński J., Budowanie kościołów z cegły palonej, „Przegląd Katolicki” 1894.

Dziekoński J., Kościół parafialny ś-go Floryana na Pradze pod Warszawa, „Architekt”, No. 1 (1900).

Dziekoński J., Kościół NP. Maryi w Krakowie, „Przegląd Techniczny” 15 (1889).

Dziekoński J., Księgi o architekturze d-ra Zubrzyckiego, „Przegląd Techniczny” 41 (1915).

Frankfort-Nachmias C., Nachmias D., Metody badawcze w naukach społecznych, Poznań 2001.

Jemielity W., Schematyzm diecezji łomżyńskiej, Łomża 1975.

Katalog Zabytków Sztuki w Polsce. Województwo podlaskie (białostockie). Powiat białostocki, eds. M. Zgliński i K. Kolendo-Korczak, Warszawa 2016.

Kleczkowski K., Analiza kształtów architektury, Warszawa 1885.

Krakowski P., Fasada dziewiętnastowieczna. Ze studiów nad architektura XIX wieku, „Zeszyty Naukowe Uniwersytetu Jagiellońskiego. Prace z Historii Sztuki”, Issue 16, 1981.

Krenz J., Architektura znaczeń, Gdańsk 1997.

Krenz J., Idea ujęta w kamień, http://www.pg.gda.pl/ jkrenz/Az/Book3.html.

Lurker M., Przesłanie symboli w mitach, kulturach i religiach, Kraków 1994.

Majdowski A., Dokumentacja prac konserwatorskich Józefa Piusa Dziekońskiego (18441927) w zakresie architektury sakralnej: w 150-lecie urodzin architekta, „Ochrona Zabytków" No. 47/2 (185) 1994.

Majdowski A., Nurt narodowy w architekturze sakralnej Królestwa Polskiego od drugiej połowy XIX wieku, in: Studia z historii architektury sakralnej w Królestwie Polskim, Warszawa 1993.

Majdowski A., $O$ „archeologii sztuki i krytycyzmie naukowym” w polskiej architekturze sakralnej drugiej połowy XIX wieku, in: Nasza Przeszłość: Studia z dziejów Kościoła i kultury katolickiej $w$ Polsce, Kraków 1991, Vol. 76.

Majdowski A., O poglądach na styl wiślano-bałtycki w polskiej architekturze sakralnej XIX wieku, w: Nasza Przeszłość: Studia z dziejów Kościoła i kultury katolickiej w Polsce, Kraków 1992, Vol. 78; Also accessible therein online: kpbc.umk.pl.

Majdowski A., Rzymskokatolickie budownictwo kultowe w twórczości projektowej Józefa P. Dziekońskiego (1844-1927), Kraków 1990.

Majdowski A., Stan badań nad twórczościa Józefa Dziekońskiego w zakresie architektury sakralnej: w 150 lecie urodzin architekta, „Ochrona Zabytków” 47/3-4 (1994).

Małachowicz E., Wrocławski zamek książęcy i kolegiata św. Krzyża na Ostrowie, Wrocław 1993.

Martynowski F. K., Zapoznane drogi w sztuce polskiej, „Przegląd Bibliograficzno-Archeologiczny" 1881.

Matuszewski K., O architekturze u obcych i u nas. Uwagi ze stanowiska estetycznego, „Biblioteka Warszawska", Vol. 3, 1881.

Medievalman0, Architektura gotycka a scholastyka, https://medievalman0.wordpress. com/2009/10/16/architektura-gotycka-a-scholastyka/. 
Nieniewski A., Architekt Józef Dziekoński, „Przegląd Techniczny”, No. 1 (1908).

Nowowieyski A., Wykład Liturgii Kościoła Katolickiego, Vol. 1, Wiadomości wstępne, part I, O środkach rozwinięcia kultu, Warszawa 1893.

Pasierb J. St., Katedra symbol Europy, Pelplin 2004.

Pisarek W., Wstęp do nauki o komunikowaniu, Warszawa 2008.

Pruszkowski J., Martyrologium, czyli męczeństwo unii na Podlasiu, part 1-2, Lublin 1905-1917.

Sas Zubrzycki J., Styl nadwiślański, Kraków 1910.

Sas Zubrzycki J., Styl polski styl narodowy, Lwów 1922.

Starzyński J., Gotyk polski, in: Świat i życie: Zarys encyklopedyczny współczesnej wiedzy i kultury, Vol. II, ed. Z. Łempicki, Lwów-Warszawa (brw).

Stefański K., Nowa forma $w$ polskiej architekturze sakralnej poczq̨tku XX wieku: Wojciechowski- Sosnowski-Wiwulski, „Saeculum Christianum: pismo historyczno-społeczne" 2003, No. 10/2.

Świt-Jankowska B., Znaczenie w architekturze detalu, „Czasopismo Techniczne. Architektura" 109 (2012), Issue 5-A/2; Also accessible online: https://suw.biblos.pk.edu.pl/ downloadResource\&mId=1088182.

Wetesko L., Romańska i wczesnogotycka architektura kościoła pocysterskiego w Oliwie (XII- XIII w.), „Nasza Przeszłość”, Issue 83, 1994.

Wilczewski W.F., Zwiastun powszechnej radości. Ruch budowy kościołów $w$ diecezji wileńskiej w latach 1890-1914, Białystok 1995.

Zanim wróciła Polska. Martyrologium ludności unickiej na Podlasiu w latach 1866-1905 w świetle wspomnień, Vol. 5, prepared by T. Krawczak, Warszawa 1994.

Żywicki J., Architektura neogotycka na Lubelszczyźnie, Lublin 1998.

\section{Biogram}

Norbert Mojżyn, an art historian and a theologist of culture; professionally involved in studying the visual communication and the theological implications of art; since 2008 Norbert Mojżyn has worked at the Cardinal Stefan Wyszynski University in Warsaw, Poland. 